Yana Us,

Sumy State University, Ukraine

(iD) ORCID ID, 0000-0003-1451-0450

email:y.us@fem.sumdu.edu.ua

Tetyana Pimonenko,

Dr.Sc., Sumy State University, Ukraine

ORCID ID, 0000-0001-6442-3684

email: tetyana pimonenko@econ.sumdu.edu.ua

Tatjana Tambovceva,

Dr.Sc., Professor, Riga Technical University, Latvia

ORCID ID, 0000-0002-9516-1530

email: tatjana.tambovceva@rtu.Iv

Jean-Pierre Segers,

Dr.Sc., Riga Technical University, Latvia

(iD) ORCID ID, 0000-0002-2252-5479

email: jean-pierre.segers@rtu.Iv

Correspondence author:y.us@fem.sumdu.edu.ua

\title{
GREEN TRANSFORMATIONS IN THE HEALTHCARE SYSTEM: THE COVID-19 IMPACT
}

Abstract. This paper summarizes the arguments and counterarguments within the scientific discussion on the healthcare systems' transformations towards sustainability, considering COVID-19 pandemic. The paper aims to forecast changes in the healthcare sector's greenhouse gas emissions of the EU countries. For gaining that purpose, the authors carried out the study in the following logical sequence. Firstly, the bibliometric analysis was conducted based on 2313 publications indexed by Scopus database. The study sample consists of 1995 publications indexed by the keywords such as healthcare, green, carbon and sustainable; and 318 publications - green, carbon-free, covid, pandemic, coronavirus and health. The fields for search are titles, keywords and abstracts. The search was limited to the subject areas such as Social science; Environmental sciences; Business, Management and Accounting; Economics, Econometrics and Finance. The time framework is 2000-2020. The scientific background analysis stated the strong relationship between implementing green innovation in the healthcare system towards gaining sustainable development goals. The obtained results indicated that the COVID-19 requires the decisive green transformation in the economy. Thus, the forecast of greenhouse gas volume from the healthcare activity (human health and social work activities; human health activities; manufacture of basic pharmaceutical products and pharmaceutical preparations) until 2030 was conducted. The methodological tool of this research based on the Autoregressive Integrated Moving Average (ARIMA) model. The software EViews 11 was used to provide empirical calculation. This study involved data of the EU countries such as Hungary, Slovakia, Malta, Denmark and Portugal from 1995 to 2019. The base of data is the EU statistical service Eurostat. Based on the obtained results, the authors concluded that there are still disparities in the healthcare sectors of the EU-countries towards sustainability. Therefore, the authors highlighted the necessity to improve the EU countries' cohesion policy, which would allow decisively and quickly cooperate to find effective solutions towards developing resilience in the healthcare sector due to implementing green strategies. The authors emphasized that this study's obtained results could be the base for future investigations devoted to effective green solutions to minimize greenhouse gas emissions from the healthcare activity.

Keywords: ARIMA, COVID-19, healthcare, carbon-free economy, green transformations.

Introduction. COVID-19 is considered the most dangerous threat for the world in the short-term perspective, while negative climate change is long-term. Despite the rapid world answer on COVID-19

Cite as: Us, Ya., Pimonenko, T., Tambovceva, T., \& Segers, J-P. (2020). Green Transformations in the Healthcare System: the COVID-19 Impact. Health Economics and Management Review, 1, 48-59. http://doi.org/10.21272/hem.2020.1-04 
Ya., Us, T., Pimonenko, T., Tambovceva, J-P., Segers . Green Transformations in the Healthcare System: the COVID-19 Impact

explosion, the severe quarantine restrictions have led to the economic crisis, which is more serious than the global financial crisis in 2008. Figure 1 shows there is a sharp decline in the economic prospects around the world. Herewith, in 2020, the GDP level in China decreased approximately by 6 times compared the previous year, in the United States - by 3.65 times, in Ukraine, Poland and Hungary - more than 2 times, while in India - by 1.76 times. Thus, the slowdown in economic growth, high government extra spending to fight against COVID-19 consequences and tightening on the credit market lead to postponing the high-priority problem in economic development. Moreover, the economic recession could prevent efforts in achieving sustainable development goals.

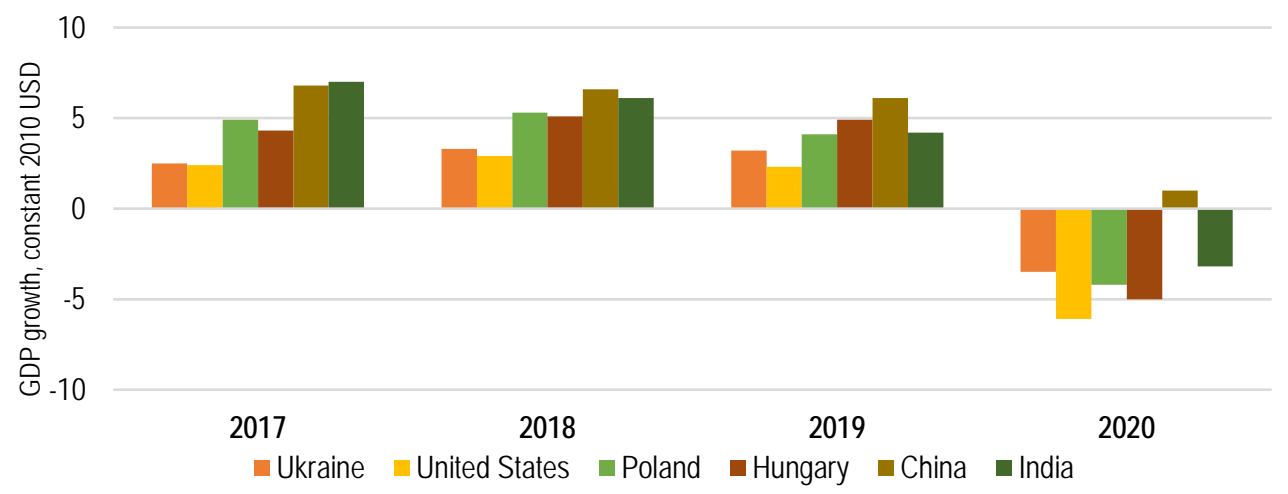

Figure 1. The dynamics of economic prospects (GDP growth, constant 2010 USD), 2017-2020 Sources: developed by the authors on the basis of (World Bank, 2020).

Nowadays, the world requires people's welfare increase by providing economic growth, social welfare, technological and innovation development. Besides, this challenge links with ensuring the ecological safety which lays in sustainable development. The fighting against COVID-19 pointed out that the governments could quickly operate, while the population change their behaviour to achieve social welfare. Hence, within the economic recovery framework, the countries should formulate an environmentally friendly and sustainable economy. It is necessary to implement decisive action to prevent harmful climate change around the world. Therefore, the economic entities investing in the green transformation would be more successful, while ones with the old economic system lose the market share.

The healthcare system function is an important body of social security in any country. Besides, it contributes to sustainable welfare due to minimizing health and economic risks. Within this framework, the healthcare sector's economic sustainability is indicative of the healthcare expenditures per cent of GDP. It stands to mention that healthcare expenditures are considered economically sustainable if they don't exceed the social benefit. However, the healthcare expenditures growth could provoke the negative influence on developing the other economic sectors.

The rapid burst of COVID-19 pandemic has pointed on the healthcare systems weaknesses of the most developed countries. It tested the strengths the national healthcare systems, their ability to resist, and the availability and speed of reaction to emergency incidents. The COVID-19 spread indicated on the necessity to strengthen the healthcare systems. The hospitals could not provide all patients with hospital beds, health personal, individual protection equipment. Besides, there is a lack of effectiveness of management and financial systems. It is worth noting that most COVID-injured countries had spent a high GDP share on developing the healthcare systems. According to the statistical data, in 2018, the USA's total health spending was $16.96 \%$ of GDP; France - 11.2\%; the United Kingdom - 9.8\%; Spain - 8.9\%; Italy $-8.8 \%$, China - 5\% (Figure 2). 
Ya., Us, T., Pimonenko, T., Tambovceva, J-P., Segers . Green Transformations in the Healthcare System: the COVID-19 Impact

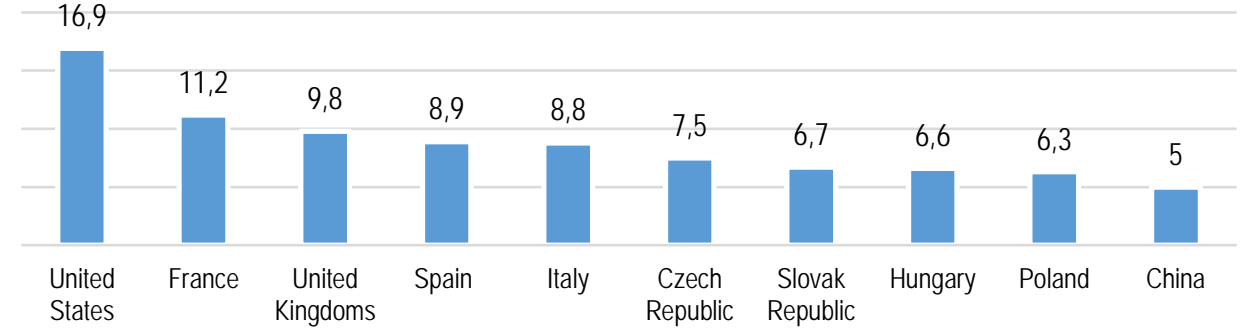

Figure 2. The total health spending in $2018, \%$ of GDP

Sources: developed by the authors on the basis of (Statista, 2020).

Despite the mentioned above, in December 2019, the number of COVID-cases per 100000 population in the USA was 1483.24; France - 798.24; the United Kingdom - 861.48; Spain - 640.29; Italy - 1346.2 (CDCP, 2020). Therefore, the most critical and challenging task for the healthcare system is its ability to quickly reorganize under crisis circumstances due to mobilization of medical personal while saving the primary medical services. The healthcare system's readiness to the emergency means providing the safety and hygiene conditions for medical personal, psychological support, and professional training for medical personal to reprofile under the healthcare system's new requirements. To prevent the spread of infection, most countries' governments directed the additional public funds to the healthcare systems. Besides stimulating and supporting the national healthcare system, the United Kingdom spent the extra 6.1 bln USD, Italy - 3.5 bln USD, Spain - 1 bln USD (ILO, 2020).

Moreover, COVID-19 showed that medical services' quality needs to be increased by optimizing the online and mobile medical service platforms, 3D printing and artificial intelligence. The propagation path of infection on the national level could be tracked using the location data from gadgets. Therefore, digital technologies' development to inform and train allows increasing the transparency and quality of medical services and administration effectiveness. According to the 10-Action Plan (Solutions, 2020) by the Sustainable Markets Council, the main economic recovery point is social welfare and environmental prosperity.

Healthcare is considered to be one of the vital economic sectors in achieving sustainable goals. However, even the well provided healthcare systems couldn't prevent the spreading of COVID-19. Most of the countries couldn't strengthen immediately. Therefore, it is essential to take global actions to develop reliable and sustainable healthcare systems. In turn, these systems would be prepared to provide fair access to qualitative medical service and resist the unexpected outbreaks such as COVID-19.

Indeed, the sustainable healthcare system improves/recovers and supports human health minimizing the negative influence on the environment to provide safe living conditions for future generations. In turn, effective management, financing, service and resources control aimed to achieve this goal. It worth noting that healthcare system becomes a more significant contributor to the environmental management because environmental sustainability activities promote the decision of the primary health disease; deliver benefits for patients, providers, medical personal; decrease the risk of adverse environmental impact on the human health; provide the realization of the primary function in the healthcare sector; facilitate cost-savings and advance the healthcare systems' resilience (WHO, 2020).

It stands to mention that the healthcare sector is a heavy consumer of energy and natural resources. Moreover, it is the primary waste and emission producer. According to resilience (Karliner et al., 2019), global healthcare systems' footprint is $4.4 \%$ of net emissions. Thus, the mention above means that the healthcare systems have a direct and indirect impact on the environment. 
Ya., Us, T., Pimonenko, T., Tambovceva, J-P., Segers . Green Transformations in the Healthcare System: the COVID-19 Impact

Therefore, nowadays, when the healthcare systems faced with the necessity to reorganize, it is necessary to prioritize the green development policy. However, the green healthcare system doesn't recognize any compromise solutions in realizing the primary healthcare functions for environmental sustainability. Hence, it is essential to assure the synergy between health and environmental sustainability to strengthen healthcare functions.

Literature Review. The systematization of scientific publications related to green healthcare development presented in the Scopus database showed the growing tendency in publication activity. Figure 3 shows that rapid publication growth was in 2014, while the share of considered publications increased by $38,5 \%$ compared to the previous year. It could be assumed that this growth resulted from the first cases of Ebola virus recorded in Africa in December 2013. In turn, since 2016 there is a constantly rising tendency in exploring the relationship between sustainability and the healthcare sector, which could be provoked by the commitment of the ambition Paris Climate Agreement to fight against adverse climate changes.

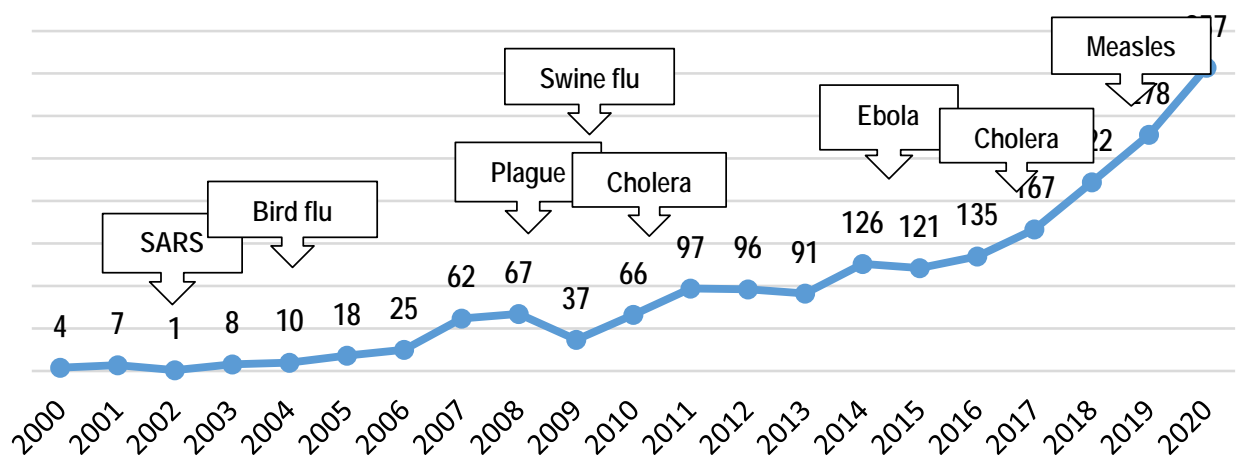

Figure 3. The dynamic of publication activity on the issues of green healthcare and major pandemics chronology, 2000-2020

Sources: developed by the authors on the basis of (Scopus, 2020; MISC, 2020)

The systematization analysis of scientific background showed that a large number of studies was devoted to the issues of negative climate challenges (Prokopenko et al., 2017; Cebula et al., 2018; Chygryn et al., 2018; Ibragimov et al., 2019; Lyulyov et al., 2015; Panchenko et al., 2020). The findings showed that many scientists investigated the relationship between COVID-19 and changes in the healthcare sector. Hence, in the study (Auner et al., 2020), the authors described the impact of COVID19 as an opportunity to decrease the healthcare sector's waste sources. Thus, scientists indicated the necessity to implement political reforms to promote sustainable changes in the healthcare sector.

Liu, L. (2020) disagreed with the Chinese government response to COVID-19. The scientist emphasized that the healthcare sector's management system was ineffective and prolonged the growth of COVID-19 injection. Besides, in the study's frame (de Jong \& Ho, 2020), the authors considered the correlation between countries' response to the COVID-19 burst depending on their economic and fiscal conditions. They concluded that policy response was similar in different countries. Moreover, there was no significant correlation with fiscal conditions in those countries. In turn, the correlation between government response and pandemic caseload was positive. Simultaneously, it was negative in mediumterm expenditures in the healthcare sector and changes in the unemployment level.

The researchers of a scientific paper (Samah et al., 2020) indicated that the healthcare sector significantly consuming energy and water resources had an adverse impact on the environment. Thus, the empirical study's findings demonstrated the influence of healthcare expenditures and healthcare 
development on the level of $\mathrm{CO} 2$ emission during COVID-19 pandemic. The authors emphasized the necessity to implement the $\mathrm{CO} 2$ emission reforms to provide the sustainable growth of the economy and healthcare sector. The study (Anser et al., 2020) estimated the impact of COVID-19 measures on the environment state. In turn, scientists noted that effective approaches to decrease CO2 emissions could prevent pandemic appearance worldwide. Pamucar et al. (2020) introduced the multi-criteria methodology to reorganize the healthcare system towards sustainability perspective considering the COVID-19 conditions.

Furthermore, the importance to develop sustainability in the healthcare sector due to innovations was highlighted in the paper (Barr et al., 2020). The authors described the telehealth idea as a future model of the healthcare system. In turn, the authors in the study (McKimm et al., 2020) emphasized education's role and increased human awareness about climate changes as a potential for green transformation, allowing for the prevention of new social and ecological difficulties.

To analyze the thematic directions of the formulated study sample, the visualization for similarities method (VOS) was applied (Van and Waltman, 2007). It stands to note that the co-occurrence of authors' keywords allowed visualizing the thematic scope of investigated publications. Herewith, the threshold for analysis was 5 keywords co-occurrence in publications. The visualized network map consists of different sized circles, links and colours. The more circle diameter is, the more times the keyword appears in the publications. The distance between two items indicates the frequency of keywords co-occurrence in the publication. The item links show the number of interactions with other items. In turn, the colours allow determining the item belonging to the specific cluster.

The study sample consists of 1995 publications indexed by the keywords such as healthcare, green, carbon and sustainable; and 318 publications - green, carbon-free, covid, pandemic, coronavirus and health. The fields for search are title, keywords and abstracts. The search was limited to the subject areas such as Social science; Environmental sciences; Business, Management and Accounting; Economics, Econometrics and Finance. The time framework is $2000-2020$. Besides, the boolean operators «AND» and «OR» was used to combine the different search results, while the wildcards asterisk - to include the different word endings.

Figure 4 visualizes the results of a bibliometric analysis of the investigated publications. Thus, there are twelve clusters characterize the scientists' research directions in green health care and COVID-19. The first biggest cluster (28 items) demonstrates that scientists aimed to investigate the relationships between healthcare and sustainability, financial performance, management, machine learning, smart healthcare, knowledge management, etc. The second cluster (25 items) shows that researchers concentrated more on investigating big data, circular economy and e-health. This cluster indicates that the publications were devoted to green transformation issues in the healthcare and improving the quality and analyzing the implementation of new technologies such as the Internet of Things, telemedicine, cloud computing, etc. The third cluster ( 23 items) indicates the relations between publications devoted to the issues of COVID-19, health and sustainable development. The researchers investigated the carbon emissions from the healthcare systems, healthcare services, etc. The fourth cluster (20 items) links the publications exploring the healthcare policy in the view of green sustainability, healthcare reforms, green space, nature, technology, etc. The fifth cluster (18 items) consists of the publications devoted to investigating the relationship between COVID-19 and air pollution. The sixth cluster (15 items) combines the articles in healthcare engineering, especially green building. In turn, the seventh cluster (14 items) consists of the publications indexed by corporate social responsibility, healthcare organizations, recycling, medical waste, etc. Thus, it could be assumed that the scientist concentrated on managing medical waste in terms of sustainability. The eights cluster (11 items) visualizes the research direction towards investigating the relationship between medical education, service quality and patient satisfaction. The ninth cluster (10 items) shows that this pool of publications aimed at investigating the issues of carbon footprint, coronavirus, healthcare, education, etc. 


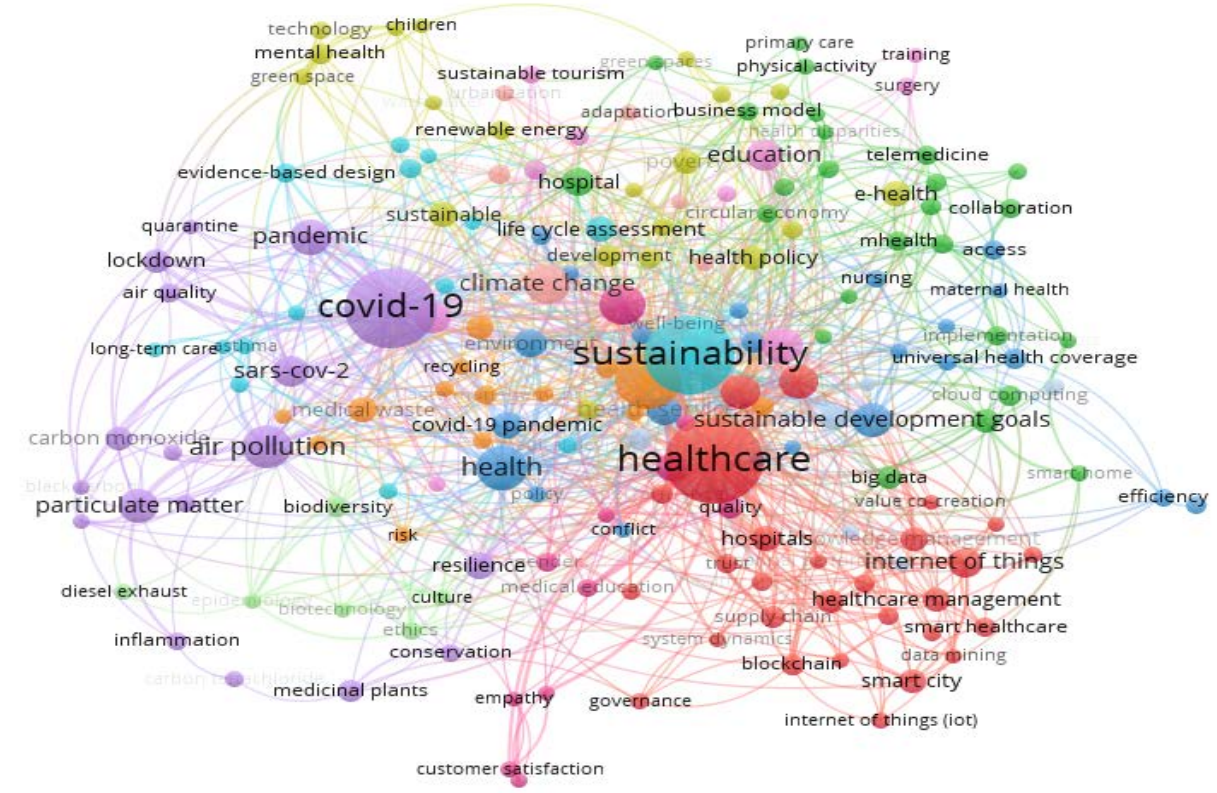

Figure 4. The visualization of the thematic directions of publications related to green healthcare and COVID-19, 2000-2020

Sources: developed by the authors on the basis of (Scopus 2020) using VOSviewer software.

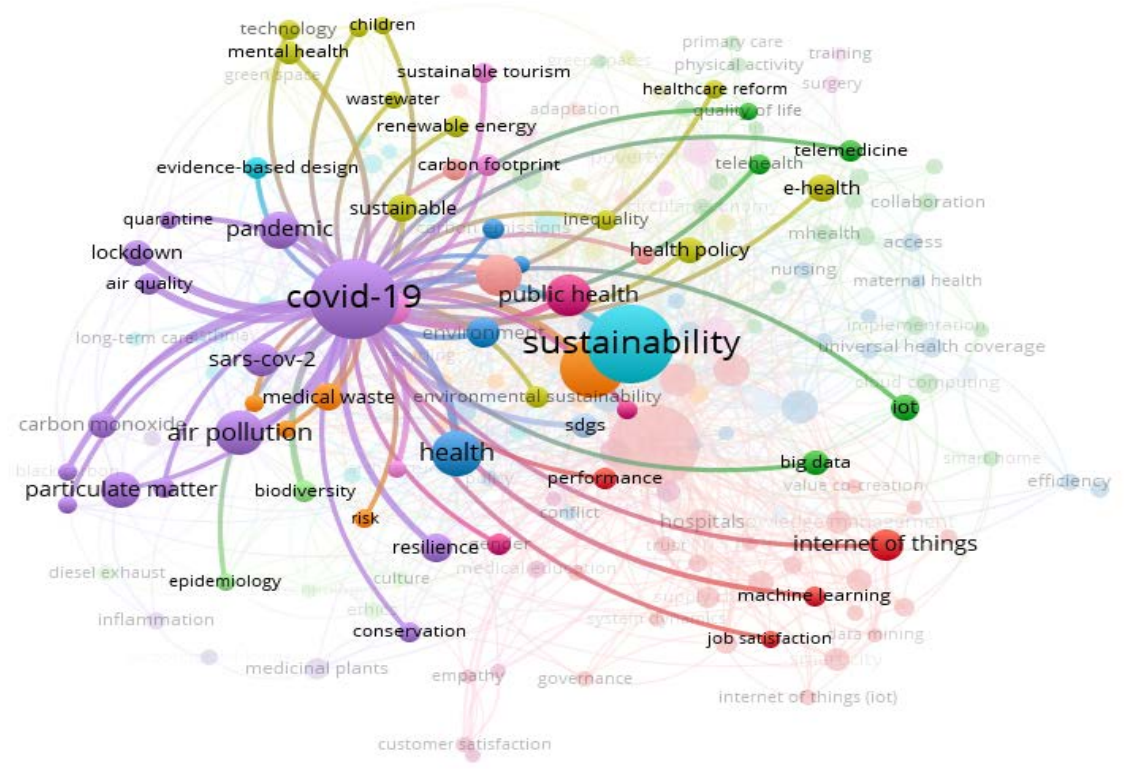

Figure 5. The visualization of co-occurrences of the keyword «COVID-19», 2000-2020 Source: developed by the authors on the basis of (Scopus 2020) using VOSviewer software. 
Figure 5 demonstrates that scientists explored the issues of COVID-19 from different points of view. In turn, the authors studied the development of new technologies in the healthcare sector (big data, Internet of things, telemedicine, machine learning, e-health) due to COVID-19. Moreover, Figure 4 indicates the strong link strength between COVID-19 and sustainable development publications, especially $\mathrm{CO} 2$ emission, renewable energy, medical waste, air and water quality, etc.

Therefore, the above analysis of scientific background indicates the relevancy to explore future development in the healthcare sector towards sustainability considering COVID-19 pandemic. Thus, this study aimed to forecast changes in the healthcare sector's $\mathrm{CO} 2$ emissions of the EU countries violently afflicted with COVID-19.

Methodology and research methods. This research's object is the EU countries viz Hungary, Slovakia, Denmark, Portugal and Malta. Thus, the volume of greenhouse gases (CO2, N2O in $\mathrm{CO} 2$ equivalent, $\mathrm{CH} 4$ in $\mathrm{CO} 2$ equivalent, $\mathrm{HFC}$ in $\mathrm{CO} 2$ equivalent, $\mathrm{PFC}$ in $\mathrm{CO} 2$ equivalent, $\mathrm{SF} 6$ in $\mathrm{CO} 2$ equivalent, NF3 in $\mathrm{CO} 2$ equivalent) from the healthcare activity (human health and social work activities; human health activities; manufacture of basic pharmaceutical products and pharmaceutical preparations) from 1995 to 2019 were analyzed to forecast its level until 2030. The software EViews 11 was used to provide empirical calculation.

It the frame of this study, the Autoregressive Integrated Moving Average (ARIMA) model was implemented to forecast the volume of greenhouse gases in the healthcare sector. It stands to mention that $\operatorname{ARIMA}(p, d, q)$ model is the extension of ARMA (Autoregressive Moving Average) model for nonstationary time series. Thus, the non-stationary series $Y_{t}$ could be modelled down to stationary due to determining the d-tuple differences (I). Therefore, based on the study (Krukov and Chernyagin, 2011), the formal description of the $\operatorname{ARIMA}(p, d, q)$ model is:

$$
\left(\Delta^{d} X_{t}\right)=\sum_{i=1}^{p} \varphi_{i}\left(\Delta^{d} X_{t-1}\right)+\varepsilon_{t}+\sum_{j=1}^{q} \theta_{j}\left(\Delta^{d} \varepsilon_{t-j}\right), \varepsilon_{t} \sim N\left(0, \sigma_{t}^{2}\right)
$$

It worth noting that the condensed formula for the $\operatorname{ARIMA}(p, d, q)$ model is as follow:

$$
\varphi(B)(1-B)^{d} X_{t}=\theta(B) \varepsilon_{t}
$$

where $\varphi, \theta$ - polynomials of degree $\mathrm{p}$ and $\mathrm{q} ; B$ - lag operator $\left(B^{j} X_{t}=X_{t-j}, B^{j} \varepsilon_{t-j}, j=\right.$ $0, \pm 1, \ldots) ; \mathrm{d}$-sequential difference order $\left(\Delta X_{t}=X_{t-1}-X_{t}=(1-B) X_{t}, \Delta^{2} X_{t}=\Delta^{2} X_{t+1}-\right.$ $\left.\Delta X_{t}=(1-B)^{2} X_{t}, \ldots\right)$.

The methodology for developing the ARIMA $(p, d, q)$ model was proposed by Box $G$. and Jenkins $G$. in 1976. According to the mentioned above, there are several steps to develop ARIMA $(p, d, q)$ model such as 1) identification; 2) assessment of parameters; 3) testing for model adequacy; 4) model implementation for the forecast.

Therefore, the first step provides the identification of the most relevant model considering the concrete process. Different numbers $(p, d, q)$ are used to model parameterizing, where $p$ is the autoregressive model, $d$ is the degree of model integration, $q$ is the moving average. Hence, these parameters are used to determine the seasonality, tendency and noise of time series.

It stands to mention that the autoregressive model (AR) with p-order is the basic one for defining the stationary process. The process of autoregression determines the current level of dependence on the previous ones. The formula for autoregression model (AR) with $p$-order is as follow

$$
Y_{t}=\varphi_{0}+\varphi_{1} Y_{t-1}+\varphi_{2} Y_{t-2}+\ldots+\varphi_{p} Y_{t-p}+\varepsilon_{t}
$$


where $Y_{t}$ - dependent variable (time-series level at the $t$-time point); $Y_{t-1}, Y_{t-2}, \ldots, Y_{t-p}-$ independent variables (the time series levels at (t-1), (t-2), $\ldots$, t-the time points); $\varphi_{0}, \varphi_{1}, \varphi_{2}, \ldots, \varphi_{p}-$ predicted coefficients; $\varepsilon_{t}$ - random walks.

The model of moving average (MA) demonstrates the dependence of the current time series values on the previous q-predictive errors:

$$
Y_{t}=\varepsilon_{t}-\omega_{1} \varepsilon_{t-1}-\omega_{2} \varepsilon_{t-2}-\ldots-\omega_{q} \varepsilon_{t-q},
$$

where $Y_{t}$ - dependent variable (time-series level at t-time point); $\varepsilon_{t-1}$ - independent variables (remains values in i-time periods); $\omega_{1}, \omega_{2}, \ldots, \omega_{q}$ - estimated coefficients.

Therefore, based on the mentioned above the $\operatorname{ARMA}(p, q)$ model combines the autoregression model $(\mathrm{AR})$ and moving average model (MA):

$$
Y_{t}=\varphi_{0}+\varphi_{1} Y_{t-1}+\varphi_{2} Y_{t-2}+\ldots+\varphi_{p} Y_{t-p}+\varepsilon_{t}-\omega_{1} \varepsilon_{t-1}-\omega_{2} \varepsilon_{t-2}-\ldots-\omega_{q} \varepsilon_{t-q}
$$

It is then necessary to assess the model by including the new model's collected optimal values on the second stage. Thus, the initial assessments of moving averages parameters have to be conducted based on the calculated autocovariance for identified $\operatorname{ARIMA}(p, d, q)$ model. Using the maximum likelihood principle and least square's method allows estimating the model parameters. In turn, the next stage provides model testing on the adequacy based on the remains of the developed stochastic model $\left(\varepsilon_{t}\right)$. Therefore, the model could be used for forecasting.

Results. The analysis of statistical data allowed stating that the volume of greenhouse gases ( $\mathrm{CO} 2$, $\mathrm{N} 2 \mathrm{O}$ in $\mathrm{CO} 2$ equivalent, $\mathrm{CH} 4$ in $\mathrm{CO} 2$ equivalent, $\mathrm{HFC}$ in $\mathrm{CO} 2$ equivalent, $\mathrm{PFC}$ in $\mathrm{CO} 2$ equivalent, SF6 in $\mathrm{CO} 2$ equivalent, NF3 in $\mathrm{CO} 2$ equivalent) from the healthcare activity (human health and social work activities; human health activities; manufacture of basic pharmaceutical products and pharmaceutical preparations) has dropping tendency in Poland, Czechia, Slovakia, Denmark and Portugal. Thus, in 2019, in Denmark, it decreased by $31.6 \%$, while in Poland - by $18.6 \%$, in Czechia - by $7 \%$, in Portugal $-8.6 \%$. Besides, the most significant decline in greenhouse gas emissions was in the Slovak republic. It stands to emphasize that the Visegrad countries show comparable results. However, the average level of greenhouse gas emission per capita in 2019 increased in Malta by $53.2 \%$ compared to 2008 , while in Hungary - in 6.6\% (Figure 6).

It stands to mention that the European Green Deal announced by the European Commission in December 2019 requires aimed to make Europe climate-neutral until 2050. To gain this ambitious goal, it is necessary to renew the legislation policy in each economic sector based on innovations, circular economy, the biodiversity, sustainable farming, etc. Therefore, considering the mentioned above, the EU countries need to provide the unique cohesion policy in the healthcare sector, considering each country's singularity to ensure carbon-neutrality.

This paper aims at forecasting the dynamics of greenhouse gas emissions in the healthcare sector in the view of developing sustainability. The research object is EU-27 countries viz Hungary, Slovakia, Portugal, Malta and Denmark. Thus, the greenhouse gas emissions (CO2, N2O in CO2 equivalent, $\mathrm{CH} 4$ in $\mathrm{CO} 2$ equivalent, $\mathrm{HFC}$ in $\mathrm{CO} 2$ equivalent, $\mathrm{PFC}$ in $\mathrm{CO} 2$ equivalent, SF6 in $\mathrm{CO} 2$ equivalent, NF3 in $\mathrm{CO} 2$ equivalent) in the healthcare sector (human health and social work activities; human health activities; manufacture of basic pharmaceutical products and pharmaceutical preparations) for EU countries were analyzed to forecast its level to 2030. The sample period was 1995-2019. 
Ya., Us, T., Pimonenko, T., Tambovceva, J-P., Segers . Green Transformations in the Healthcare System: the COVID-19 Impact

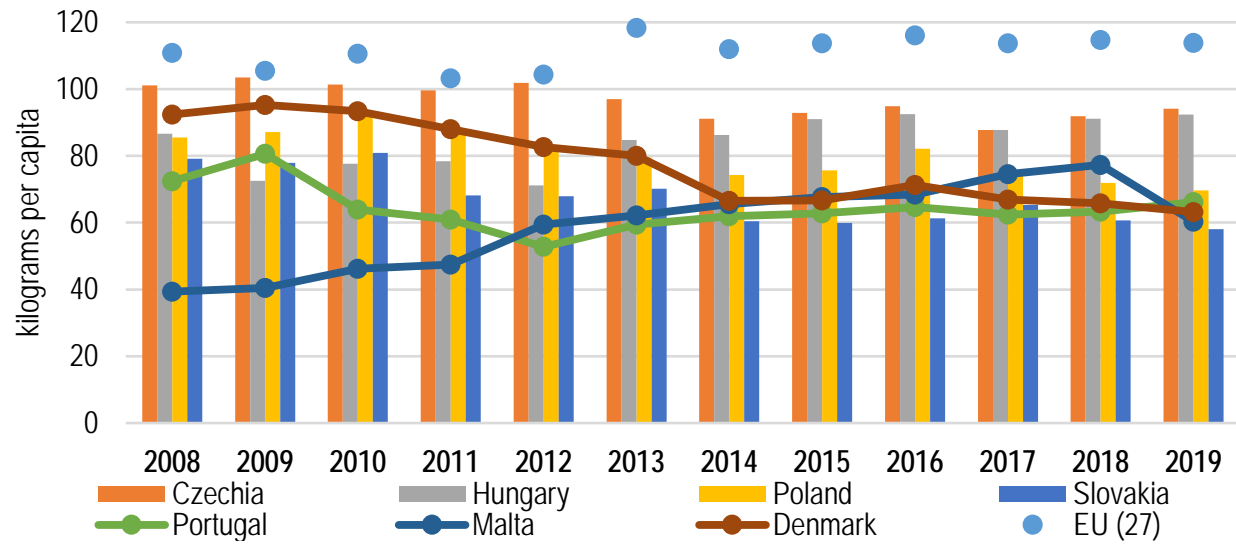

Figure 6. Greenhouse gases dynamics from healthcare activity in EU-27 countries (2008-2019) Sources: developed by the authors on the basis of Eurostat data.

The software EViews 11 was used to conduct the empirical estimation. The forecast of greenhouse gas emission dynamics has been conducted using the ARIMA model (Figure 7).

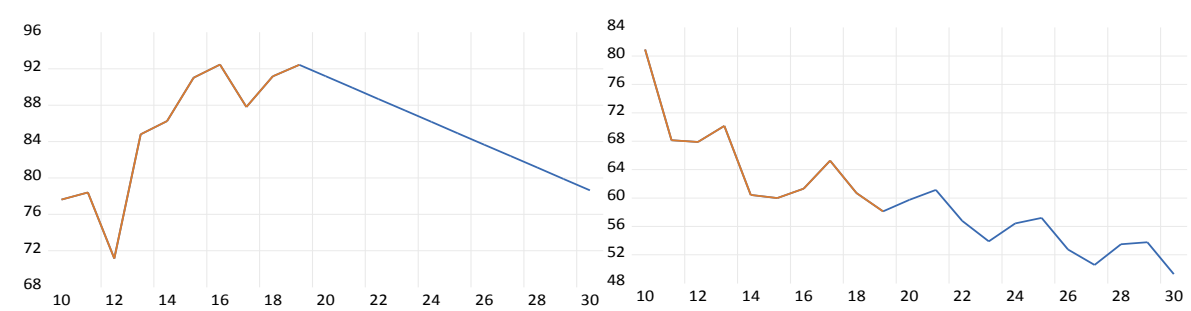

a)

b)

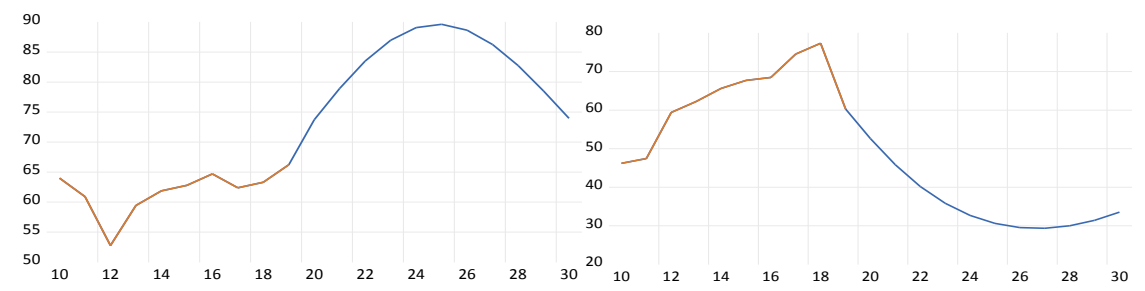

c)

d)

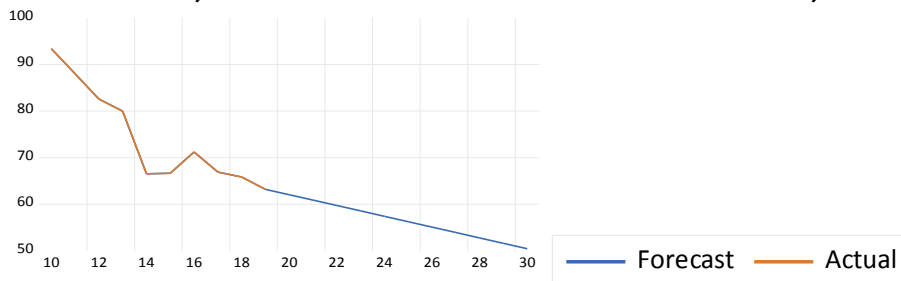

e)

Figure 7. The results of the forecast of greenhouse gas emissions (kilograms per capita) from the healthcare activity for (a) Hungary; b) Slovakia; c) Portugal; d) Malta) and e) Denmark (1995-2030) Sources: developed by the authors on the basis of Eviews software 
Ya., Us, T., Pimonenko, T., Tambovceva, J-P., Segers . Green Transformations in the Healthcare System: the COVID-19 Impact

Table 1 shows the forecast values of greenhouse gas emissions (kilograms per capita) from the healthcare activity for investigated countries. The forecast findings stated that in 2030 compared to 2019 , the healthcare sector's greenhouse gas emissions would decrease in Malta by $43.6 \%$, in Denmark - by $20.9 \%$, in Slovakia - by $15.7 \%$, while in Hungary - by $14.5 \%$. However, it is expected the increasing the level of greenhouse gas emissions by $11.75 \%$ in Portugal healthcare sector.

Table 1. Predicted values of greenhouse gas emissions from healthcare activity (kg per capita)

\begin{tabular}{c|ccccc}
$\begin{array}{c}\text { Countryl } \\
\text { Year }\end{array}$ & Hungary & Slovakia & Portugal & Malta & Denmark \\
\hline 2020 & 91 & 60 & 74 & 53 & 62 \\
2021 & 90 & 61 & 79 & 46 & 61 \\
2022 & 89 & 57 & 84 & 40 & 60 \\
2023 & 87 & 54 & 87 & 36 & 59 \\
2024 & 86 & 56 & 89 & 33 & 57 \\
2025 & 85 & 57 & 90 & 31 & 56 \\
2026 & 84 & 53 & 89 & 30 & 55 \\
2027 & 82 & 51 & 86 & 29 & 54 \\
2028 & 81 & 53 & 83 & 30 & 53 \\
2029 & 80 & 54 & 79 & 31 & 52 \\
2030 & 79 & 49 & 74 & 34 & 50
\end{tabular}

Sources: developed by the authors on the basis of Eviews software.

According to the findings, there are still disparities in the healthcare sectors of the EU-countries. Besides, COVID-19 pandemic showed that the healthcare system wasn't ready to fight against it immediately. In contrast, it should operatively react to the as unexpected diseases as caused by negative climate changes. It stands to mention that the economic recovery after COVID-19 crisis requires a green transformation in each economic sector. Moreover, it is essential to provide the EU countries' cohesion policy, allowing decisiveness and quickly cooperating to find effective solutions. Thus, fruitful collaboration would result in developing resilience in the healthcare sector due to implementing green strategies. In turn, effective green solutions would assure the minimization of greenhouse gas emissions from the healthcare activity.

The healthcare sector's green approach provides the funding of the renewable energy sources and energy efficiency; sustainable transport and water consumption; implementing the low-carbon approaches for building and projecting the hospitals; minimizing the greenhouse gas emissions and waste, etc. Therefore, the green transformation would improve human health, reduce greenhouse gas emissions, prevent adverse climate changes, reduce the burden of expenses in the healthcare sector, provide economic development, etc.

Conclusions. The rapid spread of COVID-19 pandemic indicated that the healthcare systems haven't ready to resist this challenge. Besides, the COVID-19 crisis caused large economic losses worldwide, while provided a new opportunity for green transformation. Thus, it is essential to formulate the decisive action plan to overcome the spread of COVID-19 while preventing harmful climate change worldwide. Thus, in this paper's frame, the impact of COVID-19 pandemic on the healthcare sector's transformation towards sustainability was analyzed.

The scientific backgrounds bibliometric analysis has indicated the growing publication tendency on the investigated issues in the Scopus database. The obtained results demonstrate 12 clusters which displayed the scientists' research directions in green health care and COVID-19. In turn, there is a strong link strength between COVID-19 and sustainable development publications, especially CO2 emission, renewable energy, medical waste, air and water quality, etc. 
Based on the ARIMA model with minimal parameters, thus study provides the forecast for greenhouse gas emissions (CO2, N2O in $\mathrm{CO} 2$ equivalent, $\mathrm{CH} 4$ in $\mathrm{CO} 2$ equivalent, $\mathrm{HFC}$ in $\mathrm{CO} 2$ equivalent, $\mathrm{PFC}$ in $\mathrm{CO} 2$ equivalent, SF6 in $\mathrm{CO} 2$ equivalent, NF3 in CO2 equivalent) from the healthcare sector (human health and social work activities; human health activities; manufacture of basic pharmaceutical products and pharmaceutical preparations) until 2030 for the EU countries.

The obtained results indicated that there were still disparities in healthcare development among the EU-countries. The forecast findings stated that in 2030 compared to 2019, the healthcare sector's greenhouse gas emissions would decrease in Malta (by 43.6\%), Denmark (by 20.9\%), Slovakia (by $15.7 \%)$, Hungary (14.5\%), while in Portugal - increased by $11.75 \%$. The mentioned above allowed concluding that the healthcare sector in the EU countries requires adopting the cohesion policy to decisively and quickly cooperate to fight against the COVID-19 and find effective solutions for sustainable development. Hence, effective green solutions would minimize greenhouse gas emissions from the healthcare activity and improve human health.

Author Contributions: conceptualization, methodology, software, validation, formal analysis, investigation, resources, data curation, T.P., Ya. U., T. T., J.- P. S.; writing-original draft preparation, Ya. U.; writing-review and editing, T. P. and T. T.; visualization, Ya. U.; supervision, project administration, T. P.; funding acquisition, T. P. and Ya. U.

Funding: This research was funded by the Jean Monnet Module grant (620232-EPP-1-2020-1-UAEPPJMO-MODULE) on «EU Carbon-free economy: best practices for Ukraine».

\section{References}

Anser, M. K., Yousaf, Z., Khan, M. A., Voo, X. H., Nassani, A. A., Alotaibi, S. M., ... \& Zaman, K. (2020). The impacts of COVID19 measures on global environment and fertility rate: double coincidence. Air Quality, Atmosphere \& Health, 13(9), $1083-1092$. [Google Scholar] [CrossRef]

Auener, S., Kroon, D., Wackers, E., Van Dulmen, S., \& Jeurissen, P. (2020). COVID-19: A Window of Opportunity for Positive Healthcare Reforms. International Journal of Health Policy and Management, 9(10), 419-422. [Google Scholar] [CrossRef]

Barr, J. R., D'Auria, D., \& Persia, F. (2020, September). Telemedicine, Homecare in the Era of COVID-19 \& Beyond. In 2020 Third International Conference on Artificial Intelligence for Industries (Al4I) (pp. 48-51). IEEE Computer Society. [Google Scholar] [CrossRef]

Cebula, J., Chygryn, O., Chayen, S. V., \& Pimonenko, T. (2018). Biogas as an alternative energy source in Ukraine and Israel: Current issues and benefits. International Journal of Environmental Technology and Management, 21(5-6), 421-438. [Google Scholar] [CrossRef]

Center for Disease Control and Prevention (2020). Retrieved from [Link]

Chygryn, O., Pimonenko, T., Luylyov, O., \& Goncharova, A. (2018). Green bonds like the incentive instrument for cleaner production at the government and corporate levels: Experience from EU to Ukraine. Journal of Environmental Management \& Tourism, 9(7 (31)), 1443-1456. [Google Scholar] [CrossRef]

de Jong, M., \& Ho, A. T. (2020). Emerging fiscal health and governance concerns resulting from COVID-19 challenges. Journal of Public Budgeting, Accounting \& Financial Management. [Google Scholar] [CrossRef]

Ibragimov, Z., Lyeonov, S., \& Pimonenko, T. (2019). Green investing for SDGS: EU experience for developing countries. Economic and Social Development: Book of Proceedings, 867-876. [Google Scholar]

International Labour Organization (2020). The COVID-19 Crisis and the Health Sector. Retrieved from [Link]

Karliner, J., Slotterback S., Boyd, R., Ashby, B., \& Steele, K. (2019). Health care's climate footprint. Retrieved from [Link]

Krukov, Y. A., \& Chernyagin, D. V. (2011). An Arima model for forecasting a values of network traffic. Informatsionnye Tekhnologii i Vychslitel'nye Sistemy, (2), 41-49. [Google Scholar]

Liu, L. (2020). Sustainable COVID-19 mitigation: Wuhan lockdowns, health inequities, and patient evacuation. International Journal of Health Policy and Management, 9(10), 415-418. [Google Scholar] [CrossRef]

Lyulyov, O., Chortok, Y., Pimonenko, T., \& Borovik, O. (2015). Ecological and economic evaluation of transport system functioning according to the territory sustainable development. International Journal of Ecology and Development, 30(3), 1-10. [Google Scholar]

McKimm, J., Redvers, N., El Omrani, O., Parkes, M. W., Elf, M., \& Woollard, R. (2020). Education for sustainable healthcare: leadership to get from here to there. Medical teacher, 42(10), 1123-1127. [Google Scholar] [Crosssef]

MISC (2020). Visualizing the History of Pandemics. Retrieved from [Link] 
Pamucar, D., Žižović, M., Marinković, D., Doljanica, D., Jovanović, S. V., \& Brzaković, P. (2020). Development of a Multi-Criteria Model for Sustainable Reorganization of a Healthcare System in an Emergency Situation Caused by the COVID-19 Pandemic. Sustainability, 12(18), 7504. [Google Scholar] [CrossRef]

Panchenko, V., Harust, Yu., Us, Ya., Korobets, O., \& Pavlyk, V. (2020). Energy-Efficient Innovations: Marketing, Management and Law Supporting. Marketing and Management of Innovations, 1, 256-264. [Google Scholar] [CrossRef]

Prokopenko, O., Chayen, S., Cebula, J., \& Pimonenko, T. (2017). Wind energy in Israel, Poland and Ukraine: Features and opportunities. International Journal of Ecology and Development, 32(1), 98-107. [Google Scholar]

Samah, I. H. A., Abd Rashid, I. M., Husain, W. A. F. W., Ibrahim, S., Hamzah, H., \& Amlus, M. H. (2020). The impact of healthcare expenditure and healthcare sector growth on $\mathrm{CO} 2$ emission using dynamic panel data system GMM estimation model during COVID 19 crisis. International Journal of Energy Economics and Policy, 10(6), 235. [Google Scholar]

Solutions (2020). Investing in Nature to Transform the Post COVID-19 Economy: A 10-point Action Plan to create a circular bioeconomy devoted to sustainable wellbeing. Retrieved from [Link]

Statista (2020). Retrieved from [Link]

The World Bank (2020). Global Economic Prospects. Retrieved from [Link]

Van Eck, N. J., \& Waltman, L. (2007). VOS: A new method for visualizing similarities between objects. In Advances in data analysis (pp. 299-306). Springer, Berlin, Heidelberg. [Google Scholar] [CrossRef

World Health Organization (2017). Environmentally sustainable health systems: strategic document. Retrieved from [Link]

Я.0. Ус, Сумський державний університет (Україна);

T.В. Пімоненко, д.е.н., доцент, Сумський державний університет, (Україна);

T. Тамбовцева, Dr.Sc., Professor Ризький технічний університет (Латвія);

Ж.-П. Сагерс, Dr.Sc.,Ризький технічний університет (Латвія)

Зелені трансформації в системі охорони здоров'я: вплив COVID-19

Стаття узагальнює аргументи та контраргументи в межах наукової дискусії з питання зелених трансформацій в системі охорони здоров'я, враховуючи вплив пандемії COVID-19. Основною метою проведеного дослідження є прогноз зміни об'єму викидів парникових газів у секторі охорони здоров'я на прикладі країн ЄС. Для досягнення поставленої мети, дослідження здійснено в наступній логічній послідовності. По-перше, проведено бібліометричний аналіз на основі публікацій, що проіндексовані в базі даних Scopus за такими ключовими словами: охорона здоров'я, екологічний, вуглецевий та сталий (1995 публікацій) та зелений, безвуглецевий, covid, пандемія, коронавірус, охорона здоров'я (318 публікацій). Таким чином, вихідними даними для бібліометричного аналізу обрано 2313 публікацій, опублікованих у предметних областях «Бізнес, управління та бухгалтерський облік», «Економіка, економетрика та фінанси», «Екологія». Періодом дослідження обрано 2000-2020 роки. Аналіз наукового доробку з означеної тематики дозволие зробити висновок про існування значного взаємозв'язку між впровадженням зелених інновацій в системі охорони здоров'я та досягненням иілей сталого розвитку. До того, стрімке розповсюдження COVID-19 вимагає рішучих дій в напрямку зеленої трансформації в економіці. 3 огляду на вищезазначене, у рамках дослідження здійснено прогноз динаміки зміни обсягу парникових газів у секторі охорони здоров'я (охорона здоров'я та соціальна робота; діяльність з охорони здоров'я; виробництво основних ффармацевтичних продуктів та фармацевтичних препаратів) до 2030 року. Методичним інструментарієм проведеного дослідження є модель авторегресивної інтегрованої ковзної середньої (ARIMA). Для аналізу панельних даних застосовано програмне забезпечення EViews 11. Oб'єктом дослідження $є$ країни $€$, а саме: Угорщина, Словаччина, Мальта, Данія та Португалія. Періодом дослідження обрано 1995-2019 роки. Джерелом статистичних даних є статистична служба ЄС Євростат. Результати емпіричного аналізу свідчать про те, що країни $€ С$ застосовують різні підходи для досягнення цілей сталого розвитку в секторі охорони здоров'я. Таким чином, автори наголосили на необхідності вдосконалення політики згуртованості між країнами ЄC, що сприятиме зеленим транссрормаціям в секторі охорони здоров'я. Отримані результати можуть стати основою для подальших досліджень, присвячених пошуку ефрективних екологічних рішень для мінімізації викидів парникових газів в секторі охорони здоров'я.

Ключові слова: ARIMA, COVID-19, зелені трансформації, охорона здоров'я, безвуглецева економіка.

Manuscript received: 11.08 .2020

(c) The author(s) 2020. This article is published with open access at Sumy State University. 